\title{
The Expression of Nitric Oxide in the Gingival Tissue in Subjects with Periodontitis and Chronic Pain
}

\author{
Expression de Oxido Nítrico en el Tejido Gingival de \\ Sujetos con Periodontitis y Dolor Crónico
}

\begin{abstract}
Gisele M. C. Fabri"; Paula Sannomiya*; Carla M. Prado"**; Edna A. Leick-Maldonado; Silvia Regina D. T. de

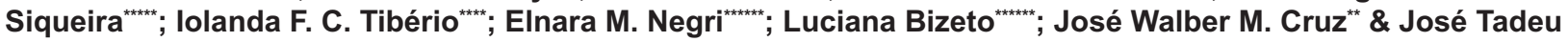
Siqueira*
\end{abstract}

FABRI, G. M. C.; SANNOMIYA, P.; PRADO, C. M.; LEICK-MALDONADO, E. A.; DE SIQUEIRA, S. R. D. T.; TIBÉRIO, I. F. C.; NEGRI, E. M.; BIZETO, L.; CRUZ, J. W. M. \& SIQUEIRA, J. T. The expression of nitric oxide in the gingival tissue in subjects with periodontitis and chronic pain. Int. J. Odontostomat., 8(2):279-287, 2014.

ABSTRACT: Periodontal disease (PD) is a chronic infection that may have local and systemic rebound. Although a series of inflammatory mediators are involved in PD, the mechanisms involved in chronic craniofacial pain associated with it require elucidation. The aim of this study was to evaluate the immunoreactivity of substance P (SP), neuronal (nNOS) and inducible (iNOS) nitric oxide synthases in gingival samples of patients with severe PD with and without chronic craniofacial pain. Gingival specimens were obtained during routine periodontal surgery while managing 20 patients with both PD and chronic craniofacial pain (CFP Group) and 18 patients with only PD (PD Group). Following surgical removal, the tissue underwent routine histological techniques and was stained by immunohistochemistry with antibodies against SP, nNOS and iNOS. Using an image analysis system, we assessed the SP, nNOS and iNOS content in total gingival tissue as well as in both epithelial and connective gingival area. We observed high expression of nNOS in gingival tissue obtained from CFP patients $(p<0.001)$, particularly in the epithelium area $(p<0.001)$ comparatively to PD patients. In addition, the iNOS expression was also increased in the CFP group in the connective gingival tissue $(p=0.003)$. There was no difference concerning SP expression between the groups. Our results suggest that nitric oxide, particularly derived from nNOS, modulates not only PD but also chronic craniofacial pain, since patients with this association presented an increase in nNOS and iNOS expression in gingival tissue.

KEY WORDS: periodontal disease, nitric oxide, orofacial pain, headache, chronic pain.

\section{INTRODUCTION}

Periodontal disease (PD) is a common chronic inflammatory condition among adult population (Albandar \& Rams, 2002). It is characterized by gingival and/or alveolar bone infection and chronic inflammation, and it has different levels of severity. It is chronic and usually painless, except in some cases when provoked by a mechanical stimulus (chewing or teeth brushing) or during an acute episode (Brunsvold \& Prakash, 1999). Considering the presence of inflammation and the rich nerve supply in the gingival tissue, PD stimulates both immune system and pain pathways (Yamazaki et al., 2004). The association of PD with some systemic conditions such as cardiovascular, metabolic and neurovascular diseases has been previously demonstrated (Amar et al., 2003; Fabri et al., 2009).

Chronic pain is a condition that remains for at least six months (Merskey \& Bogdusk, 1994) and craniofacial pain, like primary headaches or facial pain,

* Orofacial Pain Team, Hospital das Clinicas, Medical School, University of São Paulo, São Paulo, Brazil.

* Heart Institute, LIM 11, University of São Paulo, São Paulo, Brazil.

*** Department of Biological Sciences,Federal University, São Paulo, Brazil.

**** Department of Clinical Medicine, Medical School, University of São Paulo, São Paulo, Brazil.

School of Arts, Science and Humanities and Neurology Department, Medical School, University of São Paulo, São Paulo, Brazil.

${ }^{* *+* *+*}$ Medical School, University of São Paulo, São Paulo, Brazil. 
FABRI, G. M. C.; SANNOMIYA, P.; PRADO, C. M.; LEICK-MALDONADO, E. A.; DE SIQUEIRA, S. R. D. T.; TIBÉRIO, I. F. C.; NEGRI, E. M.; BIZETO, L.; CRUZ, J. W. M. \& SIQUEIRA, J. T. The expression of nitric oxide in the gingival tissue in subjects with periodontitis and chronic pain. Int. J. Odontostomat., 8(2):279-287, 2014.

is a frequent complaint among the general population (Teixeira et al., 1999). The treatment depends on accurate diagnosis (Headache Classification Subcommittee of the International Headache Society, 2004). However, even with the correct diagnostics and appropriate treatment, some patients are refractory and do not present the expected improvement due to several reasons, including the presence of an undiagnosed associated disease (Sessle, 2000; Siqueira et al., 2004).

There are several inflammatory mediators related both to general pain and PD, such as interleukins, prostaglandins and some nonadrenergic non-cholinergic (NANC) neurotransmitters (Anbar \& Gratt, 1997). Nitric oxide (NO) is a gaseous molecule that is generated during the conversion of the amino acid L-arginine into Lcitrulline by NO synthase (NOS). The main effect of nitric oxide derives from nNOS, a constitutive isoform which produces small quantities of $\mathrm{NO}$, and is related to inhibitory nonadrenergic-noncholinergic responses (Amar et al.). The inducible isoform (iNOS) produces high quantities of NO when stimulated by many proinflammatory cytokines and is expressed in several types of inflammatory cells (Ricciardolo et al., 2004). The main neurotransmitters of excitatory NANC neurotransmitter are substance $P(S P)$ and neurokinin $A$ (NKA), which play significant roles in priming and recruiting of inflammatory cells and are also related to the pain and neurogenic inflammation presented in PD (Hirose et al., 2001).

Although there is evidence that these NANC neurotransmitters are related to pain and also to periodontal inflammation, there have been no studies focusing on the role of these mediators in PD associated with craniofacial pain. In the current literature there is a lack of studies about the role of untreated chronic PD in patients complaining of chronic craniofacial pain, particularly when the pain is refractory to conventional treatments (Siqueira et al., 2004). In a previous study, we showed that patients with chronic orofacial pain or headache, with co-existing chronic periodontitis, had significant reduction in pain intensity after PD treatment (Fabri et al.). So, it is possible that chronic PD acts as a comorbidity in patients with chronic orofacial pain or headache. However, the mechanisms of this possible association are unknown. Thus, we hypothesized that the expression of NOS and SP can be up-regulated in chronic craniofacial pain associated with PD. In order to elucidate this hypothesis, we evaluated the expression of nNOS, iNOS and SP in the gingival tissue of patients who were clinically diagnosed with concomitant chronic periodontitis and chronic craniofacial pain, comparatively with the gingival tissue of patients who presented only chronic periodontal disease.

\section{MATERIAL AND METHOD}

Gingival samples were obtained from 38 subjects ( 8 males and 30 females, at a mean $\pm S D$ age of $45.38 \pm 12.0)$ diagnosed with chronic periodontitis (Armitage, 1999) and referred to periodontal treatment. The Local Ethical Committee approved this study and an informed consent was obtained.

The gingival samples were divided into two groups, according to the presence or not of concomitant chronic orofacial pain:

A. Gingival samples from patients with severe PD and concomitant chronic craniofacial pain (CFP group) ( $n=20 ; 4$ male and 16 female, mean age $48.95 \pm 13.03$ years old).

B. Gingival samples from patients that had only severe PD (PD group) $(n=18 ; 4$ male and 14 female, mean age $42.38 \pm 9.51$ years old).

The American Academy of Periodontology determines periodontal disease (PD) on the basis of the presence of concomitant edema, erythema, gingival bleeding and/or suppuration upon probing, and periodontal probing depths (Armitage). Using this classification as a general guide, extent is characterized as localized when $\leq 30 \%$ of sites are involved and generalized when $>30 \%$ of sites are involved. Severity is characterized on the basis of the amount of clinical attachment loss $(C A L)$ as follows: Slight $=1$ or $2 \mathrm{~mm}$ of CAL, Moderate $=3$ or 4 $\mathrm{mm}$ of CAL, and Severe $=\geq 5 \mathrm{~mm}$ of CAL.

The International Association for the Study on Pain defines chronic pain as a condition that remains for at least six months (Merskey \& Bogdusk).

Gingival samples. All gingival samples used in this study had been previously removed from patients who underwent periodontal surgery, and hadbeen stored. The detailed clinical characteristics of all patients who 
FABRI, G. M. C.; SANNOMIYA, P.; PRADO, C. M.; LEICK-MALDONADO, E. A.; DE SIQUEIRA, S. R. D. T.; TIBÉRIO, I. F. C.; NEGRI, E. M.; BIZETO, L.; CRUZ, J. W. M. \& SIQUEIRA, J. T. The expression of nitric oxide in the gingival tissue in subjects with periodontitis and chronic pain. Int. J. Odontostomat., 8(2):279-287, 2014.

provided the gingival samples had been previously described in a longitudinal study about the effect of periodontal treatment on craniofacial pain control, in which, the evaluation of pain of CFP group, by visual analogue scale (VAS) ranging from 0 (without pain) to 10 (worst pain), was $7.11 \pm 2.08$ (Fabri et al.). These patients had been referred to the Dentistry Division from the Neurology Department of the same hospital for the diagnosis of facial pain. The pain diagnosis in the CFP group was performed by two investigators (a neurologist and an orofacial pain dentist), following the International Headache Society criteria (Headache Classification Subcommittee of the International Headache Society).

The gingival tissue was removed at the moment of surgical incision from the area of the interdental papilla with the greatest depth of periodontal pocket, determined by probing; and which should have at least $4 \mathrm{~mm}$ of depth, and the full thickness flap should have at least $3 \mathrm{~mm}$ of width and $4 \mathrm{~mm}$ of height. The anesthesia was by blocking and not in the area of the removed gingival tissue. This criterion was used in both groups and the size of the gingival sample was similar in both.

Patients with any kind of implant tools, epileptics, pregnant women, having controlled chronic headache or orofacial pain, with dental decays, with dental pain of endodontic origin, having chronic systemic diseases or psychiatric conditions with cognitive deficit were excluded. The age, sex and periodontal parameters of patients who provided gingival samples are outlined in Table I.
Tissue preparation. Following surgical removal, the tissue was fixed with $4 \%$ buffered paraformaldehyde for $24 \mathrm{~h}$ and then transferred to $70 \%$ ethanol. The samples were processed for paraffin embedding. Histological sections with 3-4 $\mu \mathrm{m}$ sections were obtained and collected on silane-coated glass slides (DAKO, Denmark).

Immunohistochemistry for nNOS and iNOS. The immunohistochemistry method for nNOS and iNOS detection was performed as previously described (Coers et al., 1998). The samples were deparaffinized by immersion in xylol and ethanol followed by incubation with $3 \%$ hydrogen peroxide diluted in phosphate-buffered saline (PBS) solution ph-7.2 for $40 \mathrm{~min}$. Subsequently, the sections were incubated for 30 minutes at room temperature with a blocking solution containing normal mouse serum (Dako Corp., Carpinteria, CA). Monoclonal antisera raised in mice against iNOS in title of 1:200 (Calbiochem, La Jolla, CA) or a specific monoclonal IgG2a antibody to nNOS in title of 1:75 (BD Biosciences Pharmingen, San Jose, CA) was used as a primary antiserum (incubation overnight at room temperature, 1:5 and 1:50 dilution in Tris buffer, respectively). After three 5-minute washes in Trisbuffered saline (TBS), the sections were incubated with a secondary antibody (LSAB+AP Link Universal, Dako Corp., USA) for 30 minutes at $37^{\circ} \mathrm{C}$ in a humid chamber. The slides were given three more 5-minute washes in TBS and were cover-slipped with pre-diluted (for 30 minutes) alkaline phosphatase (LSAB + AP - Streptavidin AP - Dako Corp., USA). This was followed by an incubation with substrate

Table I. Age, sex and periodontal parameters of patients who provided gingival samples comparing CFP Group and PD Group.

\begin{tabular}{|c|c|c|c|}
\hline & $\begin{array}{l}\text { CFP Group } \\
(n=20)\end{array}$ & $\begin{array}{l}\text { PD Group } \\
(n=18)\end{array}$ & p \\
\hline Sex & $\begin{array}{l}F=16 \\
M=4\end{array}$ & $\begin{array}{l}F=14 \\
M=4\end{array}$ & $1.000_{-}^{1}$ \\
\hline $\begin{array}{l}\text { Age (mean) } \pm S D \\
\text { (minimum-maximum) }\end{array}$ & $\begin{array}{l}48.9 \pm 13.0 \\
(28-73)\end{array}$ & $\begin{array}{l}42.4 \pm 9.5 \\
(29-62)\end{array}$ & $0.0878{ }^{3}$ \\
\hline $\begin{array}{l}\text { PI (mean) } \pm \text { SD } \\
\text { (minimum-maximum) }\end{array}$ & $\begin{array}{l}77.8 \pm 14.62 \% \\
(51-100 \%)\end{array}$ & $\begin{array}{l}70.8 \pm 16.74 \% \\
(35-92 \%)\end{array}$ & $0.190^{3}$ \\
\hline $\begin{array}{l}\text { BOP (mean) } \pm S D \\
\text { (minimum-maximum) }\end{array}$ & $\begin{array}{l}61.02 \pm 19.6 \% \\
(16.6-93.5 \%)\end{array}$ & $\begin{array}{l}65.3 \pm 21.4 \% \\
(23.8-93.7 \%)\end{array}$ & $0.536^{3}$ \\
\hline $\begin{array}{l}\mathrm{CAL}(\text { mean }) \pm S D \\
\text { (minimum-maximum) }\end{array}$ & $\begin{array}{l}3.22 \pm 1.01 \mathrm{~mm} \\
(1.6-5.15 \mathrm{~mm})\end{array}$ & $\begin{array}{l}3.32 \pm 0.90 \mathrm{~mm} \\
(2.45-5.6 \mathrm{~mm})\end{array}$ & $0.757^{3}$ \\
\hline
\end{tabular}


FABRI, G. M. C.; SANNOMIYA, P.; PRADO, C. M.; LEICK-MALDONADO, E. A.; DE SIQUEIRA, S. R. D. T.; TIBÉRIO, I. F. C.; NEGRI, E. M.; BIZETO, L.; CRUZ, J. W. M. \& SIQUEIRA, J. T. The expression of nitric oxide in the gingival tissue in subjects with periodontitis and chronic pain. Int. J. Odontostomat., 8(2):279-287, 2014.

Fast Red TR (Sigma Chemical Co., USA) for nNOS and incubation with $0.5 \mathrm{mg} / \mathrm{ml}$ of diaminobenzidine (DAB) (Sigma Chemical Co, St Louis, MO, USA) for iNOS. Then, the samples were submitted to $0.03 \%$ of hydrogen peroxide both for 6 minutes and light hematoxylin counterstaining for 1 minute. Negative controls were obtained by the omission of primary antibodies which were substituted for $1 \%$ PBS-BSA (phosphate-buffered saline- bovine serum albumin).

Immunohistochemistry for substance $\mathbf{P}$. The immunohistochemical characterization for substance $P$ was performed using the immunoperoxidase (Avidin-Biotin-Peroxidase) method. The Samples were immersed in citrate buffer (pH-6.0) (SIGMA, Saint Louis, USA) for 20 min at 95 ? $\mathrm{C}$ in order to retrieve the antigens. The sections were incubated in $3 \%$ of normal serum diluted in distilled water, at room temperature, for $20 \mathrm{~min}$, and were sequentially incubated with rabbit antihuman substance $P$ polyclonal antibody in title 1:50 (Biomol international, PA, USA). Following the incubation period, the sections were washed with PBS and incubated with goat anti-rabbit IgG biotinylated antibodies (DAKO, Denmark) for $60 \mathrm{~min}$ at room temperature. Sections were then incubated with avidin-biotin complex (DAKO, Denmark) for 45 min at room temperature, and were incubated in solution of $5 \mathrm{mg} \mathrm{3,3} \mathrm{-Diaminobenzidine} \mathrm{(SIGMA,}$ USA) diluted in $10 \mathrm{ml} \mathrm{PBS}$ containing $180 \mathrm{ml}$ of $\mathrm{H}_{2} \mathrm{O}_{2}$ (20 vol.), for $6 \mathrm{~min}$, at room temperature. Following washing with distilled water, the slides were then counterstained with Mayer haematoxylin for $5 \mathrm{~min}$. Negative controls were obtained by the omission of primary antibodies which were substituted for $1 \%$ PBS-BSA (phosphate-buffered saline- bovine serum albumin).

Image analysis for positive area for nNOS, iNOS and Substance $\mathbf{P}$. The positive area analyses for $n N O S$, iNOS and substance $P$ expression in gingival tissue was performed by image analysis technique. The image capture was performed an IBM-PC computer connected to an image capture system, with a Sony video camera attached to an optical microscopy Leica (Leica DMR, Leica Microsystems Wetzlar $\mathrm{GmbH}$, Germany). We previously established a color background for each positive area based in different fields of samples of both groups. After we had the color background well established, we applied it in all images. A total of sixteen fields of each patient sample, randomically chosen, were analyzed at a magnification of x1000 for $\mathrm{nNOS}$ and iNOS and $\mathrm{x} 400$ for substance P. The positive immunorreactivity area was determined as a relationship between the quantity of positive area in a specific frame and the total area of the frame, using the Image analysis System "Leica Version" 1.54 (Leica Imaging Systems LTD-Accusoft Corporation) for nNOS detection and the Image analysis system IMAGE-PRO,PLUS, (Media Cyberneties, L.P., 4.1) for iNOS evaluation and SP. The gingival samples were analyzed by being distinguished by morphologic characteristics of the gingival epithelial (considering the area between basement membrane and the apical area of epithelial cells) and gingival connective tissue (the area under the basement membrane). Figure 1 shows the morphologic characteristics of the analyzed areas of both epithelial and connective tissues. The results were expressed as percentages and all morphometric measurements were performed by two people blinded to protocol design.

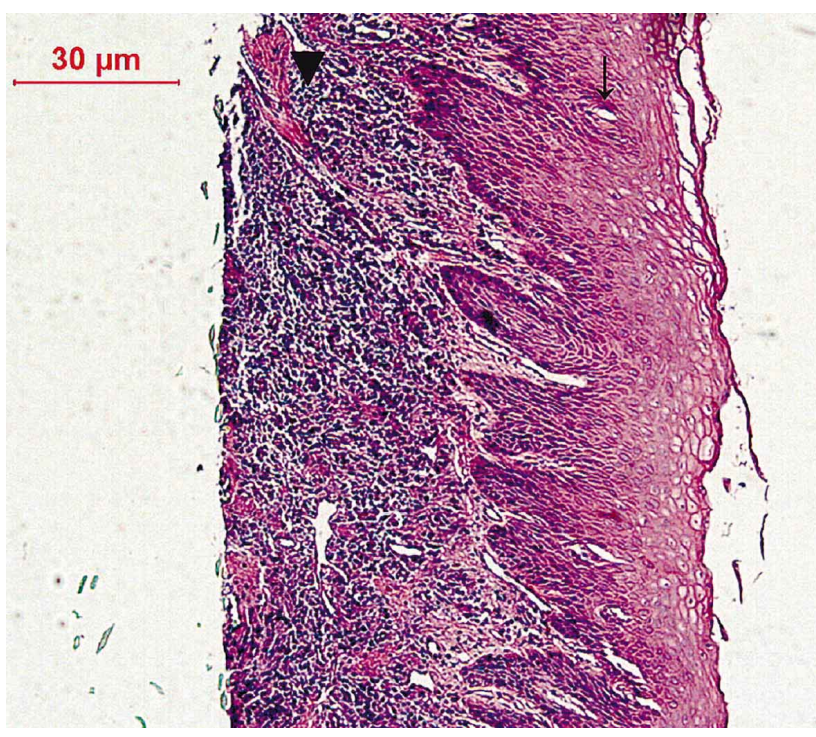

Fig. 1. Morphologic characteristics of analyzed areas, both gingival epithelium (arrows) and gingival connective tissue (head arrows). Original magnification X10 (optical microscopy).

Statistical analysis. Values were analyzed using SigmaStat software (SSI - Systat Software Inc., Richmond, CA, USA). We used the Mann-Whitney Rank Sum Test for non-parametric and t-test to parametric data. $\mathrm{P}<0.05$ values were considered significant. The graphic expression is through box plots with medians and percentiles $25 \%$ and $75 \%$ [medians (25-75\%)]. 
FABRI, G. M. C.; SANNOMIYA, P.; PRADO, C. M.; LEICK-MALDONADO, E. A.; DE SIQUEIRA, S. R. D. T.; TIBÉRIO, I. F. C.; NEGRI, E. M.; BIZETO, L.; CRUZ, J. W. M. \& SIQUEIRA, J. T. The expression of nitric oxide in the gingival tissue in subjects with periodontitis and chronic pain. Int. J. Odontostomat., 8(2):279-287, 2014.

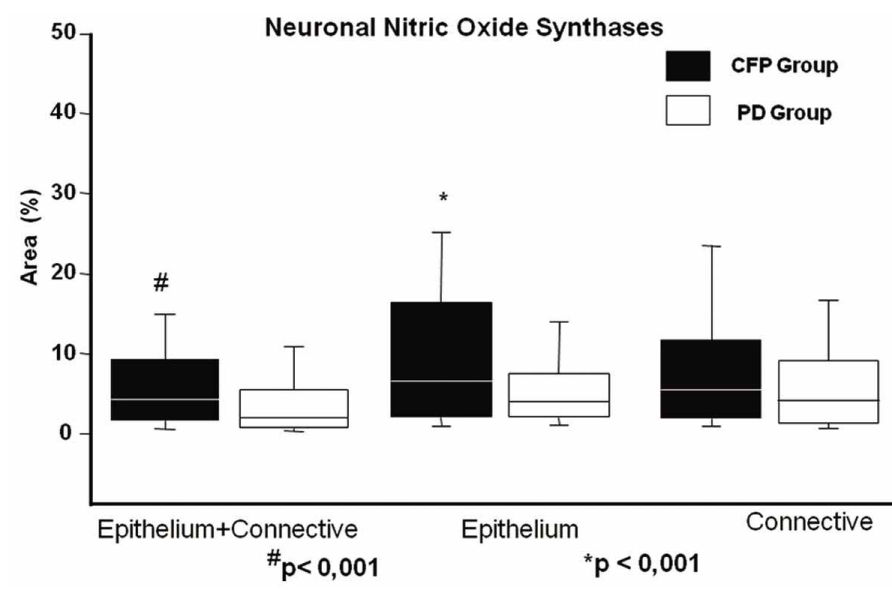

Fig. 2. n-NOS-positive area. Box Plots of percentage of nNOSpositive area (medians and percentiles) in gingival tissue from patients of CFP Group and PD Group. Statistical analysis of immune-positive area percentage (area \%) between CFP Group and PD Group in gingival tissue (\#= $p<0.001)$, just in epithelium $\left({ }^{*}=p<0.001\right)$ (Mann-Whitney test).

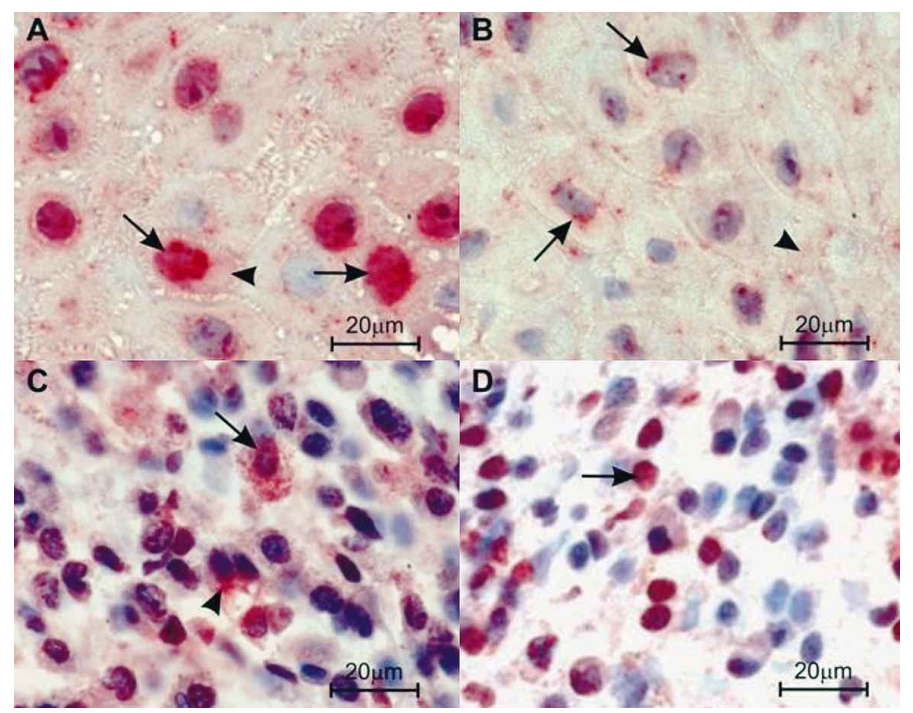

Fig. 3. Photomicrographs from gingival tissue from patients with periodontal disease submitted to immunohistochemistry stain for nNOS detection. Epithelial gingival tissue from a patient of CFP Group (A), and from a patient of PD Group (B). Connective gingival tissue from a patient of CFP Group (C), and from a patient of PD Group (D). The arrows indicate the immunorreactivity area in cell nucleus and head arrows indicate the immunorreactivity area in cell cytoplasm for $\mathrm{nNOS}$ expression. Original magnification X1000 (optical microscopy).

\section{RESULTS}

Neuronal Nitric Oxide Synthase Expression (nNOS). Figures 2 and 3 show the expression of nNOS in both epithelial and connective gingival tissue samples. In Figure
2 , we noted significant greater percentage of total nNOS-positive area in the gingival tissue of patients from the CFP Group [3.98 (1.33-8.96\%)] compared to gingival tissue of patients from the PD Group [1.72 (0.36-5.32\%)], $(p<0.001)$. In the epithelial gingival tissue, the CFP Group presented higher values [3.81 $(1.20-8.45 \%)$ compared to those obtained from the PD Group [1.19 (0.18$4.34 \%),(p<0.001)]$. There was no significant difference in the percentage of nNOS-positive area in the connective gingival tissue [CFP Group: 5.27 (1.66-11.46\%), PD Group: 3.93\% (1.10-8.87\%), $(p=0.098)]$.

In Figure 3 it is possible to observe the gingival photomicrographs from the CFP Group compared to samples from the PD Group. On a qualitative analysis, we observed a high positive stain for nNOS expression in samples.

Inducible nitric oxide synthase expression (iNOS). There was no significant difference in the percentage of iNOS-positive area in the total gingival tissue between the groups [CFP Group: 12.14 (3.29-24.5); PD Group: 7.97 (3.30-23.77), $(p=0.244)]$. However, the individual analysis in each structure (epithelial and connective gingival tissue) showed greater percentage of iNOSpositive area in the connective gingival tissue in the CFP Group [6.43 (1.86-16.08\%)] compared to the PD Group [3.84 (1.86-7.28\%), $(p=0.003)]$. There was no difference in the percentage of iNOS-positive area in the epithelial gingival tissue between the groups [CFP Group: 16.96 (5.6727.79\%) PD Group: 17.27 (6.05-29.39\%), $(p=$ $0.196)]$. These results can be observed in Figures 4 and 5 .

Substance $\mathbf{P}$ expression (SP). Figures 6 and 7 show the median values and the photomicrographs, respectively, from immunohistochemical stain for SP detection in both epithelial and connective gingival tissue. There was no significant difference in the percentage of SPpositive area in the total gingival tissue from patients studied [CFP Group: 10.39 (4.33-19.43); PD Group: $10.89(2.56-22.52),(p=0.940)]$. The individual analysis in both epithelial gingival tissue [CFP Group: 11.09 (4.64-19.29\%); PD Group: 10.11 (2.29-22.56), ( $p=0.721$ by Mann-Whitney test) and connective gingival tissue [CFP Group: 9.14 (3.19 - 19.29\%); PD Group: 12.32 (4.10-19.45\%), $(p=0.363)$ were similar between both groups. 
FABRI, G. M. C.; SANNOMIYA, P.; PRADO, C. M.; LEICK-MALDONADO, E. A.; DE SIQUEIRA, S. R. D. T.; TIBÉRIO, I. F. C.; NEGRI, E. M.; BIZETO, L.; CRUZ, J. W. M. \& SIQUEIRA, J. T. The expression of nitric oxide in the gingival tissue in subjects with periodontitis and chronic pain. Int. J. Odontostomat., 8(2):279-287, 2014.

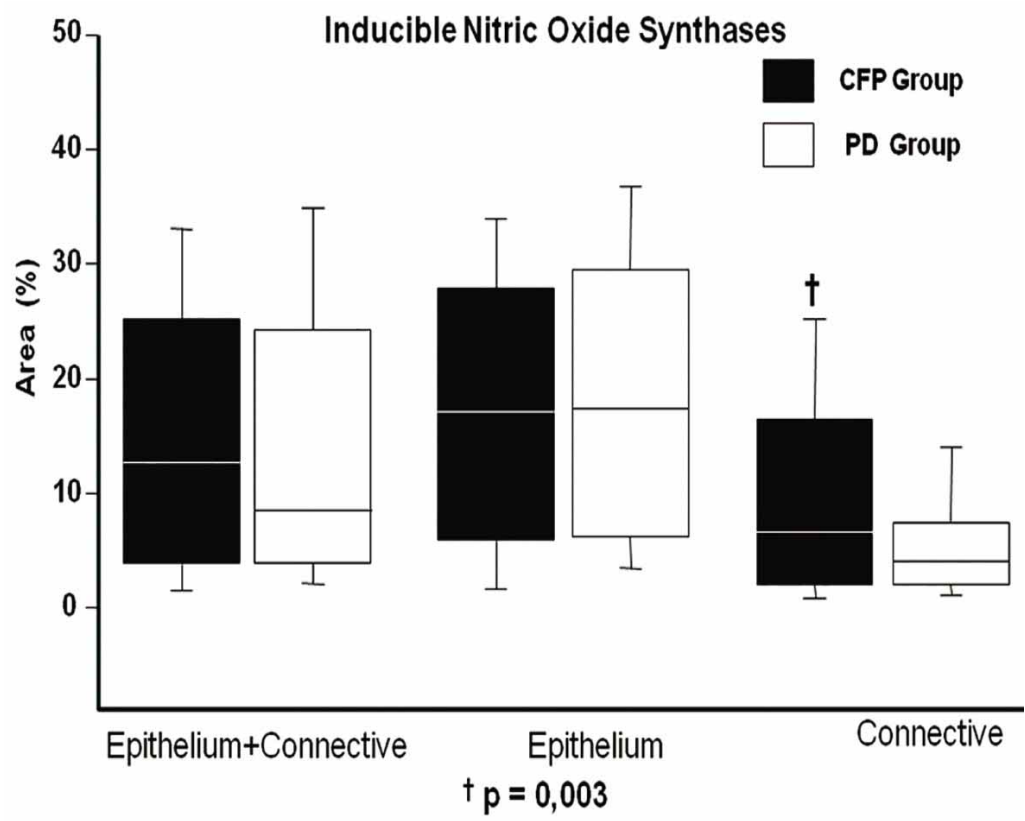

Fig. 4. i-NOS-positive area. Box Plots of percentage of iNOS-positive area (medians and percentiles) in gingival tissue from patients of CFP Group and PD Group. Statistical analysis of immune-positive area percentage (area \%) between CFP Group and PD Group in connective tissue ( $p=0.003$, Mann-Whitney test).

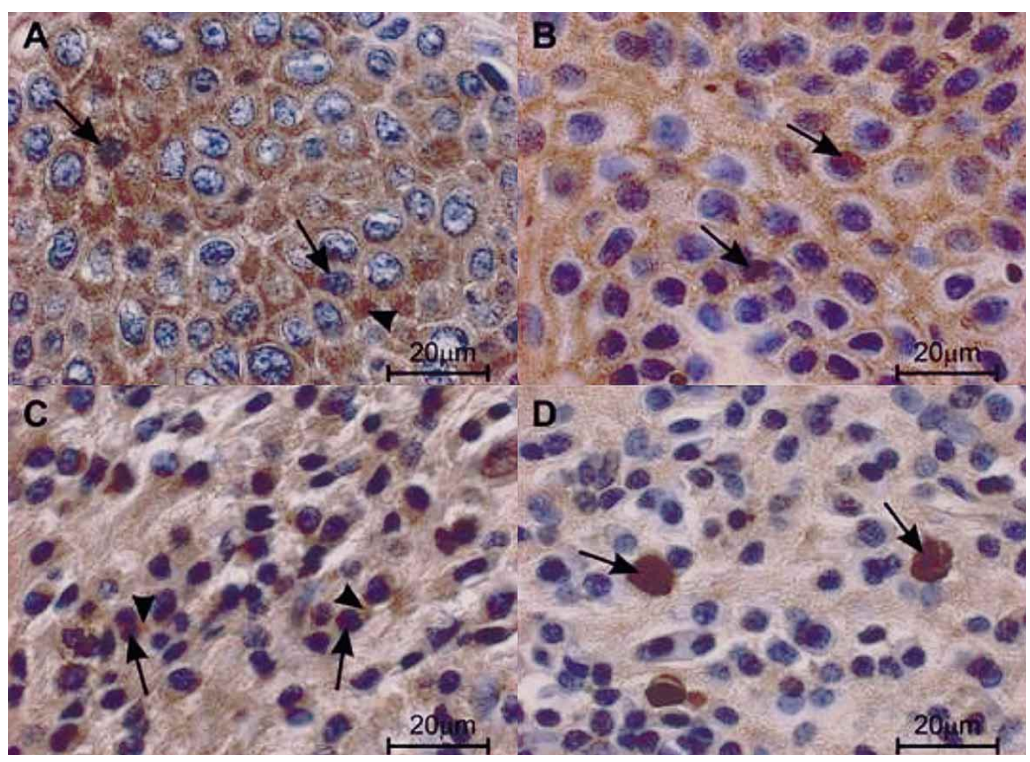

Fig. 5. Photomicrographs from gingival tissue from patients with periodontal disease submitted to immunohistochemistry stain for iNOS detection. Epithelial gingival tissue from a patient of CFP Group (A), and from a patient of PD Group (B). Connective gingival tissue from a patient of CFP Group (C), and from a patient of PD Group (D). The arrows indicate the immunorreactivity area in cell nucleus and head arrows indicate the immunorreactivity area in cell cytoplasm for iNOS. Original magnification X1000 (optical microscopy).

\section{DISCUSSION}

This study clearly shows that both nNOS and iNOS expressions were higher in the gingiva of patients with concomitant craniofacial pain and PD than in the gingiva of patients with only PD. Although there are many studies exploring the role of PD as a chronic infection with implications for several systemic diseases (Ishikawa et al., 1997; Yamazaki et al.), there is a lack of studies on chronic pain due to PD.

Therefore, studies of this kind are important for managing these chronic disorders, which are very prevalent. Recent studies have demonstrated that inflammatory markers and the immunologic system are related to pain conditions not only due to inflammation in the peripheral tissues, but also at the central nervous system by the glia (Semmler et al., 2005), which can also happen in trigeminal pain owing to the peripheral infection or inflammation (Semmler et al.). Despite the important central mechanisms in chronic or persistent pain, peripheral components should be considered and remain targets of clinical care and research. The evaluation of neurotransmitters in the gingival tissue is a model of study that we have been using in order to analyze the peripheral tissue of patients with congenital insensitivity to pain (Siqueira et al., 2006). The gingival tissue sample provide the advantage of being easily removed, it involves a brief healing process, represents a fraction of the trigeminal nerve and enables the analysis of peripheral components of the trigeminal nervous system.

Although both $\mathrm{NO}$ and substance $P$, classical NANC neurotransmitters, are implied in both pathophysiology of chronic pain (Anbar \& Gratt) and PD (Lappin et al., 2000) as well, including primary headache conditions (Anbar \& Gratt), there are no studies acknowledged so far which investigate its behavior in patients 
FABRI, G. M. C.; SANNOMIYA, P.; PRADO, C. M.; LEICK-MALDONADO, E. A.; DE SIQUEIRA, S. R. D. T.; TIBÉRIO, I. F. C.; NEGRI, E. M.; BIZETO, L.; CRUZ, J. W. M. \& SIQUEIRA, J. T. The expression of nitric oxide in the gingival tissue in subjects with periodontitis and chronic pain. Int. J. Odontostomat., 8(2):279-287, 2014.

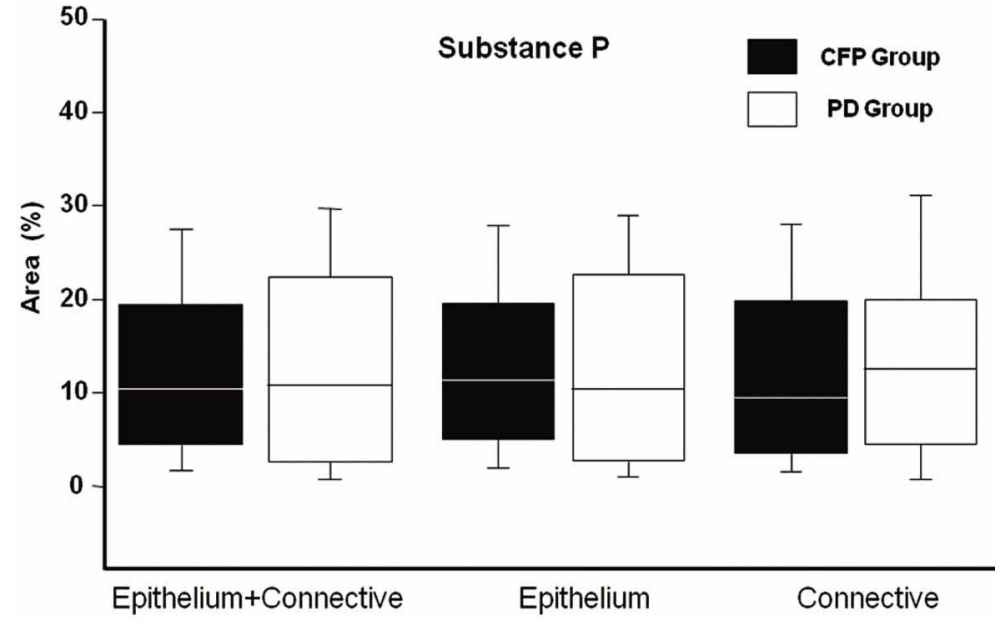

Fig. 6. SP-positive area. Box Plots of percentage of SP-positive area (medians and percentiles) in gingival tissue from patients of CFP Group and PD Group. There were no statistical differences between groups.

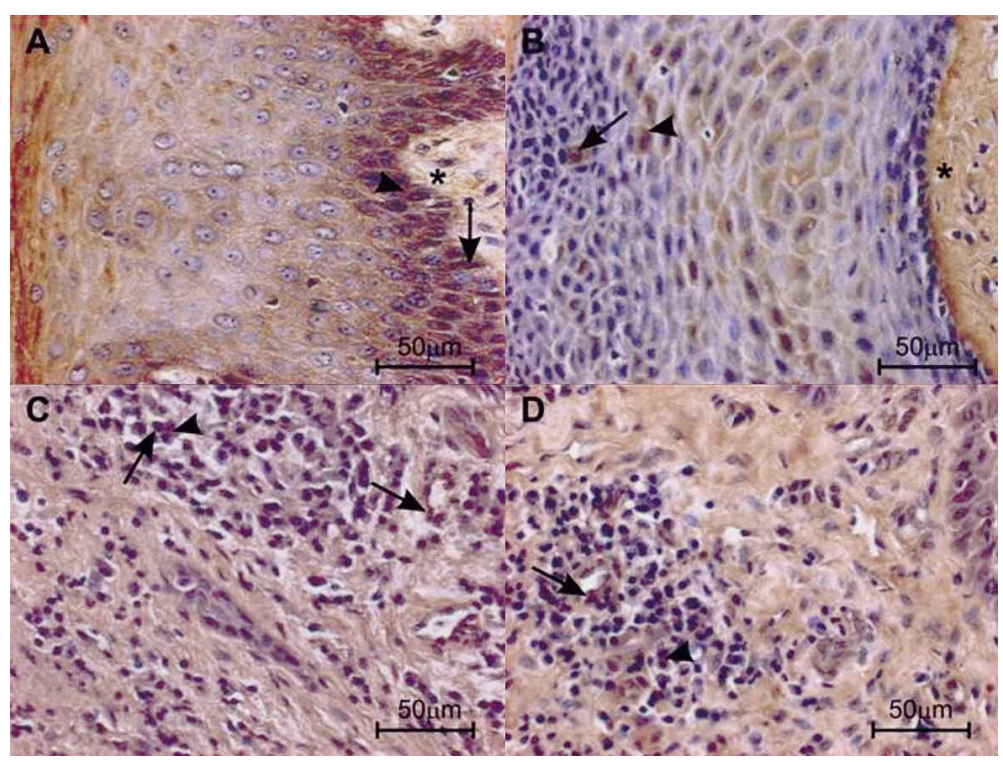

Fig. 7. Photomicrographs from gingival tissue from patients with periodontal disease submitted to immunohistochemistry stain for Substance $P$ detection. Epithelial gingival tissue from a patient of CFP Group (A), and from a patient of PD Group (B). Connective gingival tissue from a patient of CFP Group (C), and from a patient of PD Group (D). The arrows indicate the immunorreactivity area in cell nucleus and head arrows indicate the immunorreactivity area in cell cytoplasm for SP expression. Original magnification X400 (optical microscopy).

showing both conditions concomitantly, namely, chronic periodontal disease and chronic craniofacial pain. The periodontal tissue is innervated by mielinized nervous fibers strongly associated with blood vessels. The nerve endings originate in the subepithelial connective tissue and are present in the junctional epithelial tissue releasing NANC mediators (Sessle). In this study, we evaluated the gingival expression of $\mathrm{sP}$ and $\mathrm{NO}$ since both are related to the mechanisms of persistent pain (Anbar \& Gratt) and both are also related to the pathophysiology of PD (Lappin et al., 2000) and some primary headaches as well (Goodale, 1981). These analyses were made in the total sample and epithelial or connective tissues. It is possible that inflammatory cells are infiltrated in these samples and associated with extracellular matrix components.

The main discovery of the present study was the significant increase of nNOS in the gingiva, both in the epithelial and in the connective tissue, removed from patients who had concomitant PD and craniofacial pain. Interestingly, studies in patients with primary headache conditions, like migraine and tension-type headache, had shown that NO is related to the pathophysiology of such disorders, being able of triggering and maintaining chronic pain in experimental conditions (Anbar \& Gratt). Such difference of NO cannot be explained exclusively by the fact that it is also related to the pathophysiology of PD (Lappin et al.), because both groups evaluated had the same severity of PD.

Studies about NO and PD do not make clear in detail the participation of each one of the isoforms in the disease, most of them suggested that the isoform most involved is the iNOS (Lappin et al.). In the present study we showed that iNOS expression was higher in connective gingival tissue in patients from the CFP group ( $p=0.003)$, without changes in the epithelial area. The reason for such alterations are not clear yet, however, it is important to remember that the connective tissue presented more inflammatory cells population than the epithelial area (Brossardt \& Lang, 2005) as we commented above. Considering that iNOS is primary expressed in inflammatory cells, it could be a possibility to explain our findings.

Substance $P$ had been included in this study due to its role in neurogenic inflammation and chronic pain (Geppetti et al., 2008) as well as for being related to the 
FABRI, G. M. C.; SANNOMIYA, P.; PRADO, C. M.; LEICK-MALDONADO, E. A.; DE SIQUEIRA, S. R. D. T.; TIBÉRIO, I. F. C.; NEGRI, E. M.; BIZETO, L.; CRUZ, J. W. M. \& SIQUEIRA, J. T. The expression of nitric oxide in the gingival tissue in subjects with periodontitis and chronic pain. Int. J. Odontostomat., 8(2):279-287, 2014.

pathogeneses of PD. Interestingly, there were not significant differences between both groups concerning this matter $(p=0.940)$. However, studies have shown that vascular alterations in experimental models triggered by substance $\mathrm{P}$ can be mediated by NO responses (Ralevic et al., 1995), what indicates that there is interaction between these two neurotransmitters. Similar response occurs in glia cells of rats with inflammatory pain in the masseter muscles (Warren et al., 2007).

The implication and the mechanisms that might be related to such interaction between NANC mediators, peripheral and centrally produced, have not been acknowledged so far. Therefore, the difference of these mediators, mainly in nitric oxide found in patients from the CFP group, could have several complex explanations.

Our aim was not to classify or to study different types of orofacial pain, but only to verify whether there are connections between chronic pain and concomitant chronic periodontal disease. Although in the last years new sources of information about the relation between infection and chronic pain have been published, this is the first paper which presents data that provide insights into the role of chronic dental infection and pain.

In conclusion, by means of the applied methodology in this study, great values of nNOS and iNOS in the gingival tissue of patients who had chronic PD with co-existing chronic craniofacial pain were observed. These results open new possibilities concerning the role of chronic PD as a comorbidity of craniofacial pain. It can contribute to new therapeutic strategies with important clinical implications.

\section{ACKNOWLEDGEMENTS}

This study was supported by Hospital das Clínicas of Medical School of University of São Paulo, Fundação de Amparo à Pesquisa do Estado de São Paulo - FAPESP (grant No 2007/00934-2), and Coordenação de Aperfeiçoamento de Pessoal de Ensino Superior CAPES (33001010177P7).

FABRI, G. M. C.; SANNOMIYA, P.; PRADO, C. M.; LEICK-MALDONADO, E. A.; DE SIQUEIRA, S. R. D. T.; TIBÉRIO, I. F. C.; NEGRI, E. M.; BIZETO, L.; CRUZ, J. W. M. \& SIQUEIRA, J. T. Expression de oxido nítrico en el tejido gingival de sujetos con periodontitis y dolor crónico. Int. J. Odontostomat., 8(2):279-287, 2014.

RESUMEN: La enfermedad periodontal (EP) es una patología crónica que pueden tener acción local y sistémica. A pesar de que hay una serie de mediadores inflamatorios implicados en la EP, los mecanismos implicados en el dolor craneofacial crónico asociado con la EP aún no están elucidados. El objetivo fue evaluar la inmunoreactividad de la sustancia P (SP), óxido nítrico sintetasas neuronal ( $\mathrm{nNOS}$ ) e inducible (iNOS) en muestras gingivales de pacientes con enfermedad periodontal severa con y sin dolor craneofacial crónico. Fueron obtenidas muestras gingivales durante la cirugía periodontal rutinaria de 20 pacientes que presentaron con EP y dolor craneofacial crónico (Grupo PPC) y 18 pacientes sólo con PD (Grupo PD). Después de la extirpación quirúrgica, el tejido se sometió a las técnicas histológicas de rutina y se tiñó por inmunohistoquímica con anticuerpos contra el SP, nNOS e iNOS. Se evaluaron el contenido de SP, nNOS e iNOS en el tejido gingival total, así como la superficie gingival, epitelio y tejido conectivo mediante análisis de imagen. Se observó alta expresión de nNOS en el tejido gingival obtenido a partir de pacientes PPC $(p<0,001)$ en comparación a los pacientes con EP, particularmente en el área de epitelio $(p<0,001)$. Además, la expresión de iNOS se incrementó en el tejido conjuntivo gingival $(p=0,003)$ del grupo PPC. No hubo diferencia en la expresión de SP entre los grupos. Nuestros resultados sugieren que el óxido nítrico, en particular derivado de nNOS, modula no sólo PD, sino también el dolor craneofacial crónico, ya que los pacientes con esta asociación presentan un aumento de la expresión de nNOS e iNOS en el tejido gingival .

PALABRAS CLAVE: enfermedad periodontal, oxido nítrico, dolor orofacial, dolor de cabeza, dolor crónico.

\section{REFERENCES}

Albandar, J. M. \& Rams, T. E. Global epidemiology of periodontal diseases: an overview. Periodontol. 2000, 29:7-10, 2002.

Amar, S.; Gokce, N.; Morgan, S.; Loukideli, M.; Van Dyke, T. E. \& Vita, J. A. Periodontal disease is associated with brachial artery endothelial dysfunction and systemic inflammation. Arterioscler. Thromb. Vasc. Biol., 23(7):1245-9, 2003.

Anbar, M. \& Gratt, B. M. Role of nitric oxide in the physiopathology of pain. J. Pain Symptom Manage., 14(4):225-54, 1997. 
FABRI, G. M. C.; SANNOMIYA, P.; PRADO, C. M.; LEICK-MALDONADO, E. A.; DE SIQUEIRA, S. R. D. T.; TIBÉRIO, I. F. C.; NEGRI, E. M.; BIZETO, L.; CRUZ, J. W. M. \& SIQUEIRA, J. T. The expression of nitric oxide in the gingival tissue in subjects with periodontitis and chronic pain. Int. J. Odontostomat., 8(2):279-287, 2014.

Armitage, G. C. Development of a classification system for periodontal diseases and conditions. Ann. Periodontol., 4(1):1-6, 1999.

Bosshardt, D. D. \& Lang, N. P. The junctional epithelium: from health to disease. J. Dent. Res., 84(1):9-20, 2005.

Brunsvold, M. A.; Nair, P. \& Oates, T. W. Jr. Chief complaints of patients seeking treatment for periodontitis. J. Am. Dent. Assoc., 130(3):359-64,1999.

Coers, W.; Timens, W.; Kempinga, C.; Klok, P. A. \& Moshage, $\mathrm{H}$. Specificity of antibodies to nitric oxide synthase isoforms in human, guinea pig, rat, and mouse tissues. J. Histochem. Cytochem., 46(12):1385-92,1998.

Fabri, G. M.; Siqueira, S. R.; Simione, C.; Nasri, C.; Teixeira, M. J. \& Siqueira, J. T. Refractory craniofacial pain: is there a role of periodontal disease as a comorbidity? Arq. Neuropsiquiatr., 67(2B):474-9, 2009.

Geppetti, P.; Nassini, R.; Materazzi, S. \& Benemei, S. The concept of neurogenic inflammation. BJU Int., 101(Suppl. 3):2-6, 2008.

Goodale, D. B. The role of substance P in simultaneously mediating oral pain and inflammation. Anesth. Prog., 28(2):41-3, 1981.

Headache Classification Subcommittee of the International Headache Society. The International Classification of Headache Disorders: 2nd ed. Cephalalgia, 24 (Suppl. 1):9-160, 2004.

Hirose, M.; Ishihara, K.; Saito, A.; Nakagawa, T.; Yamada, S. \& Okuda, K. Expression of cytokines and inducible nitric oxide synthase in inflamed gingival tissue. J. Periodontol., 72(5):590-7, 2001.

Ishikawa, I.; Nakashima, K.; Koseki, T.; Nagasawa, T.; Watanabe, H.; Arakawa, S.; Nitta, H. \& Nishihara, T. Induction of the immune response to periodontopathic bacteria and its role in the pathogenesis of periodontitis. Periodontol. 2000, 14:79-111, 1997.

Lappin, D. F.; Kjeldsen, M.; Sander, L. \& Kinane, D. F. Inducible nitric oxide synthase expression in periodontitis. J. Periodontal Res., 35(6):369-73, 2000.

Merskey, H. \& Bogduk, N. Classification of chronic pain. 2nd ed. Seattle, IASP Press, 1994.

Ralevic, V.; Khalil, Z.; Helme, R. D. \& Dusting, G. J. Role of nitric oxide in the actions of substance $P$ and other mediators of inflammation in rat skin microvasculature. Eur. J. Pharmacol., 284(3):231-9, 1995.
Ricciardolo, F. L.; Sterk, P. J.; Gaston, B. \& Folkerts, G. Nitric oxide in health and disease of the respiratory system. Physiol. Rev., 84(3):731-65, 2004.

Semmler, A.; Okulla, T.; Sastre, M.; Dumitrescu-Ozimek, L. \& Heneka, M. T. Systemic inflammation induces apoptosis with variable vulnerability of different brain regions. J. Chem. Neuroanat., 30(2-3):144-57, 2005.

Sessle, B. J. Acute and chronic craniofacial pain: brainstem mechanisms of nociceptive transmission and neuroplasticity, and their clinical correlates. Crit. Rev. Oral. Biol. Med., 11(1):57-91, 2000.

Siqueira, J. T.; Ling, H. C.; Nasri, C.; Siqueira, S. R.; Teixeira, M. J.; Heir, G. \& Valle, L. B. Clinical study of patients with persistent orofacial pain. Arq. Neuropsiquiatr., 62(4):98896, 2004.

Siqueira, S. R.; Okada, M.; Lino, A. M.; Teixeira, M. J. \& Siqueira, J. T. Proposal for a standardized protocol for the systematic orofacial examination of patients with Hereditary Sensory Radicular Neuropathy. Int. Endod. J., 39(11):905-15, 2006.

Teixeira, M. J.; Marconi, R. M.; Rocha, R. O. \& Figueiró, J. B. Epidemiologia clínica da dor. Rev. Med., 78:36-54, 1999.

Warren, G. L.; Summan, M.; Gao, X.; Chapman, R.; Hulderman, T. \& Simeonova, P. P. Mechanisms of skeletal muscle injury and repair revealed by gene expression studies in mouse models. J. Physiol., 582(Pt 2):825-41, 2007.

Yamazaki, K.; Ueki-Maruayama, K.; Honda, T.; Nakajima, T. \& Seymour, G. J. Effect of periodontal treatment on the serum antibody levels to heat shock proteins. Clin. Exp. Immunol., 135(3):478-82, 2004.

Correspondence to:

José T. T. de Siqueira

Rua Maria Candida, 135

02071-010 - São Paulo - SP

BRAZIL

Email address: jtts@uol.com.br

Received: 09-05-2014

Accepted: 08-07-2014 